\title{
HUBUNGAN PENGUASAAN KOSAKATA DENGAN KEMAMPUAN MENULIS PUISI PADA SISWA KELAS X IIS SMA NEGERI 1 CIGUDEG BOGOR
}

\author{
Gugun Gunawan
}

\author{
Institut Ummul Quro Al-Islami Bogor \\ Jln. Moh. Noh Nur No. 112 Leuwiliang Bogor 16640 Telp. (0251) 8649408 \\ gandrung2605@gmail.com
}

Naskah masuk: 10-01-19, direvisi: 10-02-19, diterima: 10-03-19, dipublikasi: 25-04-19

\begin{abstract}
Abstrak: Penelitian ini merupakan penelitian yang mencari solusi dalam mengembangkan kemampuan menulis puisi. Penelitian ini bertujuan untuk mengetahui kesesuaian sebuah teori yang menyampaikan bahwa kegiatan menulis membutuhkan suatu penguasaan kosakata yang baik. Jika siswa memiliki kosakata yang banyak, maka akan mempermudah siswa dalam merangkai kata untuk menulis puisi. Metode yang digunakan dalam penelitian ini adalah metode korelasional. Penelitian korelasi merupakan penelitian yang melihat hubungan antara variabel atau beberapa variabel dengan variabel lain. Adapun objek penelitian ini adalah siswa kelas X IIS SMA Negeri 1 Cigudeg Bogor. Hasil dari penelitian ini menunjukkan telah terjadinya suatu korelasi antara variabel $X$ dengan variabel $Y$. Hal ini dibuktikan dengan hasil pengujian bahwa $\mathbf{r} \boldsymbol{x} \boldsymbol{y}$ hitung sebesar 0,520. Dan $\mathbf{r} \boldsymbol{x} \boldsymbol{y}$ tabel pada korelasi product moment yaitu $\mathbf{0 , 4 0 3}$. Perbandingan nilai tersebut berarti $r$ hitung lebih besar daripada $r$ tabel, $(\mathbf{0 , 5 2 0}>\mathbf{0 , 4 0 3 )}$. Jadi, hasil pengujian dengan rumus koefisien korelasi yaitu POSITIF. Oleh karena itu, kegiatan menulis yang dilakukan siswa memiliki hubungan yang sangat signifikan, jika penguasaan kosakatanya lebih baik.

Kata kunci: penguasaan kosakata, kemampuan menulis puisi
\end{abstract}

\begin{abstract}
This research is a research that seeks solutions in developing the ability to write poetry. This study aims to determine the suitability of a theory which states that writing activities require a good mastery of vocabulary. If students have a large vocabulary, it will make it easier for students to compose words to write poetry. The method used in this study is the correlational method. Correlation research is research that looks at the relationship between variables or several variables with other variables. The object of this research is class X IIS 1 Cigudeg High School Bogor. The results of this study indicate that there has been a correlation between variable $X$ and variable $Y$. This is evidenced by the results of testing that $\boldsymbol{r} \boldsymbol{x y}$ counts at $\mathbf{0 . 5 2 0}$. And the $r$ xy table in product moment correlation is $\mathbf{0 . 4 0 3}$. Comparison of these values means that the $r$ count is greater than $r$ table, $(0.520>0.403)$. So, the test resultan with the correlation coefficient formula are POSITIVE. Therefore, writing activities carried out by students have a very significant relationship, if the mastery of vocabulary is better.
\end{abstract}

Keywords: vocabulary mastery, ability to write poetry

\section{PENDAHULUAN}

Dalam melaksanakan kegiatan pengajaran di sekolah, pasti memiliki suatu tujuan pembelajaran yang diharapkan secara bersama. Tujuan pembelajaran merupakan perilaku hasil belajar yang diharapkan terjadi, dimiliki, atau dikuasai oleh peserta didik setelah mengikuti kegiatan pembelajaran tertentu (Hariyanto, 2012). Tujuan tersebut tertanam bagi stakeholder lembaga pendidikan, baik 
tujuan secara umum maupun tujuan secara khusus.

Di dalam kegiatan pembelajaran di sekolah terdapat beberapa mata pelajaran yang memiliki tujuan akhirnya adalah menghasilkan sebuah karya. Dan salah satu mata pelajaran yang memiliki tujuan khusus untuk melahirkan suatu karya yaitu mata pelajaran bahasa Indonesia. Mata pelajaran ini memberikan pengajaran kepada siswa untuk mengasah keterampilan-keterampilan yang dimiliki dalam mata pelajaran bahasa Indonesia yaitu keterampilan mendengarkan, keterampilan membaca, keterampilan berbicara, dan keterampilan menulis. Dari keempat keterampilan ini yang menjadi fokus pada hasil pembelajaran bahasa Indonesia dan bisa dijadikan sebagai bukti nyata yaitu karya tulis.

Karya tulis merupakan sebuah karya yang dihasilkan dari pemikiran atau gagasan dan dituliskan dalam salah satu media tulis untuk menjadikan bidang pengetahuan baru. Karya tersebut dihasilkan dari proses belajar mengasah keterampilan-keterampilan berbahasa Indonesia. Jadi, keterampilan menulis merupakan proses pembelajaran untuk menghasilkan suatu kemampuan siswa yang baik untuk melahirkan karya tulis yang dijadikan sebagai tujuan pembelajaran.

Karya tulis juga merupakan tulisan yang dihasilkan dari kegiatan menulis dengan menggunakan media tulis sebagai alat perangkai kata untuk berkomunikasi dengan orang lain. Hal ini dinyatakan oleh Gustiana (2013) dalam artikelnya bahwa "Writing is one of those four language skills, which is used as one medium to communicate with others, in academic field, as well as in daily life." Yang artinya menulis merupakan salah satu keterampilan berbahasa yang digunakan sebagai salah satu medium untuk berkomunikasi dengan orang lain di bidang akademis serta dalam kehidupan sehari-hari. Dengan kegiatan komunikasi yang dilakukan melalui media tulis atau kegiatan menulis dapat memudahkan penyampaian pesan atau gagasan kepada orang lain. Kegiatan Menulis juga merupakan suatu keterampilan berbahasa yang dipergunakan untuk berkomunikasi secara tidak langsung, tidak secara tatap muka dengan orang lain (Tarigan, 2008:3). Jadi, berkomunikasi secara tidak langsung (menulis), siswa memiliki kesempatan dan kemudahan untuk memilih kata-kata dengan baik sesuai tujuan penulisannya itu sendiri.

Kegiatan menulis memberikan dampak yang signifikan dalam pengembangan pola pikir seseorang yang sedang belajar menulis. Karena menulis merupakan proses melahirkan tulisan yang berisi gagasan. Kegiatan menuangkan gagasan itulah yang membuat seseorang memiliki kemampuan mengolah pemikirannya untuk mencari perbendaharaan kata atau kosakata yang tepat dalam menyampaikan pesan atau maksud dari penulis itu sendiri. Oleh karena itu, menulis membutuhkan pengalaman, waktu, kesempatan, dan latihan keterampilan menulis (Marsini, 2018).

Terkadang, seseorang tidak memiliki kesempatan dan latihan untuk meningkatkan kemampuan memilih kata dengan baik. Hal inilah yang menyebabkan kebingungan dalam membaca hasil tulisannya. Hal itu juga dikarenakan kemampuan seseorang dalam menuangkan gagasannya ke dalam sebuah tulisan itu dipengaruhi oleh latar belakang si penulis itu sendiri. Bagi seseorang yang memiliki kebiasaan membaca akan terasa mudah dalam 
menguraikan kata-katanya, ketimbang dengan orang yang tidak memiliki kebiasaan membaca akan terasa sulit dalam menguraikan kata dan kalimat. Dengan demikian, dampak dari kebiasaan tersebut akan tersimpan kosakata dalam otaknya sebagai tempat untuk memilih kata dalam menulis.

Kosakata adalah perbendaharaan kata atau banyaknya kata yang dimiliki suatu bahasa (Rama, 2008:117). Banyaknya kosakata ini sangat diperlukan seseorang atau siswa sebagai pemilik bahasa dalam mengembangkan kemampuan kegiatan menulis. Karena dengan menguasainya kosakata, seseorang akan mudah dalam menuangkan pikirannya sesuai dengan maksud yang ingin disampaikan kepada pembaca. Hal ini sesuai dengan pernyataan Diah Ayu Kristina dalam artikelnya mengatakan bahwa adanya hubungan positif antara penguasaan kosakata yang tinggi dengan meningkatkan kemampuan menulis pada siswa. Jadi, memiliki kosakata yang banyak merupakan hal yang wajib dalam kegiatan menulis.

Dari uraian di atas, penulis ingin membuktikan pernyataannya dengan memberikan tugas menulis puisi kepada salah satu sekolah tingkat SMA sederajat di Bogor. Kemudian kegiatan menulis puisi termasuk dalam materi pembelajaran di sekolah yang harus dikuasai oleh siswa. Sebagaimana yang telah tercantum dalam kurikulum 2013 revisi 2017 bahwa siswa dilatih untuk memiliki keterampilan berbahasa dengan baik. Dan keterampilan tersebut yaitu keterampilan menulis puisi.

Puisi merupakan salah satu karya sastra yang banyak manfaatnya bagi pembaca. Hal ini bisa dirasakan jika penggunaan kata-katanya menyentuh emosi, dan menggunakan bentuk karangan yang terikat oleh rima atau ritma. Menurut Joko Santoso (2017:117) bahwa Puisi adalah bentuk karangan yang terikat oleh rima/irama, ataupun jumlah baris serta ditandai oleh bahasa yang padat. Dari kepadatan dan keterikatan inilah yang membuat puisi jadi indah dan mampu menyentuh emosi pembaca, karena puisi memiliki bahasa secara emosional. Hal ini sesuai dengan pernyataan Susanti dalam artikelnya (2018) bahwa puisi merupakan bentuk karya sastra hasil pemikiran manusia yang diungkapkan dalam bahasa emosional, berirama, artistik, serta imajinatif yang mempunyai struktur fisik dan struktur batin. Jadi sangat pentinglah siswa menguasai dalam menulis puisi. Walaupun banyak yang mengatakan bahwa menulis puisi itu seni yang paling sulit untuk dihayati secara langsung sebagai totalitas. Tetapi, justru di situlah pesan yang ingin disampaikan kepada pembaca untuk menelaah atau memahami indahnya dalam menulis puisi. Dan kunci untuk menulis puisi yang indah dan bermanfaat perlu penguasaan kosakata yang baik.

Oleh karena itu, penelitian ini bermaksud untuk mencari kebenaran dan mengetahui secara total dengan menguji suatu teori-teori yang telah diuraikan sebelumnya bahwa kunci dari kegiatan menulis untuk menghasilkan sebuah karya tulis yang baik khususnya bidang menulis puisi yaitu dengan memilikinya kemampuan untuk menguasai kosakata yang banyak. Bagaimanakah hasil tes penguasaan kosakata dan tes kemampuan menulis puisi dengan tema "alam lingkungan" yang akan diberikan kepada responden (siswa kelas X IIS). Apakah penguasaan kosakata dengan kemampuan menulis puisi pada siswa kelas X IIS SMAN 1 Cigudeg Bogor 
terdapat hubungan yang signifikan. Jika hasilnya signifikan atau terdapat kesesuaian korelasi antara variabel $X$ dengan variabel $Y$ maka teori yang telah diuraikan di atas secara jelas terdapat kebenaran atau kesesuaian yang bisa digunakan oleh pembaca atau masyarakat keilmuan sebagai wawasan baru.

\section{METODE}

Penelitian ini menggunakan metode korelasional. Penelitian korelasi adalah penelitian yang akan melihat hubungan antara variabel atau beberapa variabel dengan variabel lain (Riyanto, 2010:34). Metode ini digunakan untuk membuktikan ada tidaknya hubungan masalah yang diteliti pada siswa kelas X IIS SMAN 1 Cigudeg Kabupaten Bogor. Adapun teknik dalam mengambil sampel dari sebuah populasi yaitu menggunakan model Cluster Random Sampling. Model Cluster Random Sampling adalah satu sampel acak sederhana dari kluster dari elemenelemen (Silalahi, 2015:404). Dengan sistem acak secara berkelompok atau dalam hal ini kelas, semua responden mendapatkan kesempatan untuk menjadi sampel. Dan hasilnya adalah X IIS 1 yang berjumlah 40 siswa.

Dalam kegiatan mengumpulkan data, peneliti mengambil data dari dua sumber, yakni nilai penguasaan kosakata dan nilai menulis puisi pada siswa kelas $X$ IIS SMA Negeri 1 Cigudeg Bogor. Dan alat untuk mengumpulkan data yang akan digunakan dalam penelitian ini sebagai berikut.

Tabel 1. Kisi-kisi variabel X (Penguasaan Kosakata)

\begin{tabular}{|c|l|l|}
\hline No & \multicolumn{1}{|c|}{ Indikator } & \multicolumn{1}{c|}{ Jumlah Soal } \\
\hline 1. & $\begin{array}{l}\text { Menunjukkan kata } \\
\text { sesuai dengan } \\
\text { uraian yang } \\
\text { tersedia }\end{array}$ & $1,2,3,4,5,6,8,10$. \\
\hline
\end{tabular}

\begin{tabular}{|c|c|c|}
\hline 2. & $\begin{array}{l}\text { Menunjukkan } \\
\text { sinonim kata yang } \\
\text { tersedia }\end{array}$ & $\begin{array}{l}11,12,13,14, \\
15,16,17,18, \\
19,20 .\end{array}$ \\
\hline 3. & $\begin{array}{l}\text { Menunjukkan } \\
\text { antonim kata yang } \\
\text { tersedia }\end{array}$ & $\begin{array}{l}21,22,23,24, \\
25,26,27,28, \\
29,30,\end{array}$ \\
\hline 4. & $\begin{array}{l}\text { Menjelaskan arti } \\
\text { kata dengan kata- } \\
\text { kata atau } \\
\text { menggunakan } \\
\text { kalimat }\end{array}$ & $\begin{array}{l}31,32,33,34, \\
35,36,37,38, \\
39,40 .\end{array}$ \\
\hline
\end{tabular}

Tabel 2. Kisi-kisi variabel Y (Kemampuan Menulis Puisi)

\begin{tabular}{|c|c|c|c|c|}
\hline No. & Elemen & Indikator & $\begin{array}{l}\text { Bo } \\
\text { bot }\end{array}$ & Total \\
\hline \multirow{3}{*}{1.} & \multirow{3}{*}{ Diksi } & Baik & 10 & \multirow{3}{*}{20} \\
\hline & & Cukup & 6 & \\
\hline & & $\begin{array}{c}\text { Kurang } \\
\text { baik }\end{array}$ & 4 & \\
\hline \multirow{3}{*}{2.} & \multirow{3}{*}{ Pengimajian } & Baik & 10 & \multirow{3}{*}{20} \\
\hline & & Cukup & 6 & \\
\hline & & $\begin{array}{c}\text { Kurang } \\
\text { baik }\end{array}$ & 4 & \\
\hline \multirow{3}{*}{3.} & \multirow{3}{*}{ Kata Konkret } & Baik & 10 & \multirow{3}{*}{20} \\
\hline & & Cukup & 6 & \\
\hline & & $\begin{array}{c}\text { Kurang } \\
\text { baik }\end{array}$ & 4 & \\
\hline \multirow{3}{*}{4.} & \multirow{3}{*}{ Majas } & Baik & 10 & \multirow{3}{*}{20} \\
\hline & & Cukup & 6 & \\
\hline & & $\begin{array}{c}\text { Kurang } \\
\text { baik }\end{array}$ & 4 & \\
\hline \multirow{3}{*}{5.} & \multirow{3}{*}{ Versifikasi } & Baik & 10 & \multirow{3}{*}{20} \\
\hline & & Cukup & 6 & \\
\hline & & $\begin{array}{c}\text { Kurang } \\
\text { baik }\end{array}$ & 4 & \\
\hline
\end{tabular}

Selanjutnya, prosedur atau langkah yang dilakukan dalam penelitian ini adalah 1)observasi pada SMAN 1 Cigudeg Bogor, 2)memberikan teori pembelajaran tentang kosakata dan puisi, 3)pengambilan data dengan tes penguasaan kosakata dan menulis puisi dengan tema lingkungan alam, 4)mengidentifikasi data dari hasil tes, 5)analisis data dengan menggunakan rumus Product moment (Dolet, 2013:164), 6)menarik simpulan. 
HASIL DAN PEMBAHASAN

Berdasarkan dari kegiatan tes penguasaan kosakata dan tes kemampuan menulis puisi dengan tema lingkungan alam yang dilakukan oleh peneliti kepada siswa kelas X IIS SMA Negeri 1 Cigudeg Bogor dengan jumlah responden yaitu 40 siswa bahwa terdapat nilai yang termasuk kategori baik. Nilai tersebut dilihat dari rata-rata yang diperoleh siswa kelas $X$ IIS SMA Negeri 1 Cigudeg Bogor. Adapun untuk melihat nilai yang telah diperoleh siswa, peneliti sajikan secara jelas pada tabel di bawah ini.

Tabel 3. Skor Nilai Perolehan Kosakata

\begin{tabular}{|c|c|c|c|c|c|c|c|}
\hline 55 & 65 & 75 & 80 & 85 & 85 & 85 & 95 \\
\hline 60 & 70 & 75 & 80 & 85 & 85 & 85 & 95 \\
\hline 65 & 70 & 75 & 80 & 85 & 85 & 90 & 95 \\
\hline 65 & 70 & 75 & 80 & 85 & 85 & 90 & 100 \\
\hline 65 & 75 & 75 & 80 & 85 & 85 & 90 & 100 \\
\hline
\end{tabular}

Tabel 4. Skor Nilai Perolehan Menulis Puisi

\begin{tabular}{|l|l|l|l|l|l|l|l|}
\hline 44 & 52 & 60 & 68 & 72 & 76 & 84 & 92 \\
\hline 48 & 52 & 68 & 68 & 76 & 76 & 84 & 92 \\
\hline 48 & 52 & 68 & 68 & 76 & 76 & 84 & 92 \\
\hline 48 & 56 & 68 & 72 & 76 & 80 & 84 & 92 \\
\hline 48 & 60 & 68 & 72 & 76 & 84 & 88 & 92 \\
\hline
\end{tabular}

Data yang sudah terkumpul kemudian peneliti analisis sesuai dengan rumus yang telah ditentukan untuk mengetahui hubungan antara penguasaan kosakata dengan kemampuan menulis puisi, maka dilakukan perhitungan korelasi product moment dengan rumus sebagai berikut.

$$
r \mathrm{xy}=\frac{n \sum X Y-\left(\sum X\right)\left(\sum Y\right)}{\sqrt{\left\{n \sum x^{2}-\left(\sum x\right)^{2}\right\}\left\{n \sum Y^{2}-\left(\sum Y\right)^{2}\right\}}}
$$

Selanjutnya, untuk memudahkan peneliti dalam mengolah data untuk mengetahui hubungan antara penguasaan kosakata dengan kemampuan menulis puisi, maka peneliti membuat tabel sebagai berikut. Tabel 5. Analisis Nilai antara Kosakata dan Menulis Puisi

\begin{tabular}{|c|c|c|c|c|c|}
\hline Resp. & $\mathrm{X}$ & $\mathrm{Y}$ & $\mathrm{XY}$ & $X^{2}$ & $Y^{2}$ \\
\hline $\mathrm{A}$ & 80 & 76 & 6080 & 6400 & 5776 \\
\hline $\mathrm{B}$ & 100 & 84 & 8400 & 10000 & 7056 \\
\hline $\mathrm{C}$ & 80 & 92 & 7360 & 6400 & 8464 \\
\hline $\mathrm{D}$ & 70 & 76 & 5320 & 4900 & 5776 \\
\hline $\mathrm{E}$ & 80 & 68 & 5440 & 6400 & 4624 \\
\hline $\mathrm{F}$ & 65 & 76 & 4940 & 4225 & 5776 \\
\hline $\mathrm{G}$ & 75 & 72 & 5400 & 5625 & 5184 \\
\hline $\mathrm{H}$ & 85 & 76 & 6460 & 7225 & 5776 \\
\hline $\mathrm{I}$ & 80 & 52 & 4160 & 6400 & 2704 \\
\hline $\mathrm{J}$ & 75 & 68 & 5100 & 5625 & 4624 \\
\hline $\mathrm{K}$ & 85 & 88 & 7480 & 7225 & 7744 \\
\hline $\mathrm{L}$ & 75 & 68 & 5100 & 5625 & 4624 \\
\hline $\mathrm{M}$ & 95 & 92 & 8740 & 9025 & 8464 \\
\hline $\mathrm{N}$ & 85 & 68 & 5780 & 7225 & 4624 \\
\hline $\mathrm{O}$ & 95 & 60 & 5700 & 9025 & 3600 \\
\hline $\mathrm{P}$ & 85 & 76 & 6460 & 7225 & 5776 \\
\hline $\mathrm{Q}$ & 60 & 48 & 2880 & 3600 & 2304 \\
\hline $\mathrm{R}$ & 85 & 48 & 4080 & 7225 & 2304 \\
\hline $\mathrm{S}$ & 95 & 68 & 6460 & 9025 & 4624 \\
\hline $\mathrm{T}$ & 100 & 72 & 7200 & 10000 & 5184 \\
\hline $\mathrm{U}$ & 80 & 84 & 6720 & 6400 & 7056 \\
\hline $\mathrm{V}$ & 65 & 56 & 3640 & 4225 & 3136 \\
\hline $\mathrm{W}$ & 55 & 76 & 4180 & 3025 & 5776 \\
\hline $\mathrm{X}$ & 75 & 60 & 4500 & 5625 & 3600 \\
\hline $\mathrm{Y}$ & 65 & 44 & 2860 & 4225 & 1936 \\
\hline $\mathrm{Z}$ & 85 & 72 & 6120 & 7225 & 5184 \\
\hline $\mathrm{AA}$ & 85 & 92 & 7820 & 7225 & 8464 \\
\hline $\mathrm{BB}$ & 85 & 84 & 7140 & 7225 & 7056 \\
\hline $\mathrm{CC}$ & 90 & 68 & 6120 & 8100 & 4624 \\
\hline $\mathrm{DD}$ & 90 & 48 & 4320 & 8100 & 2304 \\
\hline $\mathrm{EE}$ & 85 & 84 & 7140 & 7225 & 7056 \\
\hline $\mathrm{FF}$ & 70 & 80 & 5600 & 4900 & 6400 \\
\hline $\mathrm{GG}$ & 85 & 52 & 4420 & 7225 & 2704 \\
\hline $\mathrm{HH}$ & 90 & 76 & 6840 & 8100 & 5776 \\
\hline $\mathrm{II}$ & 65 & 92 & 5980 & 4225 & 8464 \\
\hline $\mathrm{JJ}$ & 85 & 52 & 4420 & 7225 & 2704 \\
\hline $\mathrm{KK}$ & 75 & 48 & 3600 & 5625 & 2304 \\
\hline $\mathrm{LL}$ & 70 & 92 & 6440 & 4900 & 8464 \\
\hline $\mathrm{MM}$ & 75 & 68 & 5100 & 5625 & 4624 \\
\hline & & & & & \\
\hline
\end{tabular}




\begin{tabular}{|c|c|c|c|c|c|}
\hline NN & 85 & 84 & 7140 & 7225 & 705kriteria sedang sebesar $42,5 \%$. Ketig \\
\hline $\begin{array}{c}\sum N= \\
40\end{array}$ & 3137 & 2840 & 228640 & 262050 & $\begin{array}{l}\text { yang termasuk kelompok kriteria tinggi } \\
\text { 209696 } 5 \text { ebesar } 15 \% \text {. Dan keempat, kelompok }\end{array}$ \\
\hline
\end{tabular}

Nilai di atas, peneliti pindahkan pada rumus yang telah ditentukan untuk menguji suatu hubungan antara variabel $X$ dan variabel $\mathrm{Y}$. Adapun hasil pemindahan dari rumus yang telah ditentukan peneliti sebagai berikut.

$$
\begin{aligned}
& r x y=40 \times 228640-(3137)(2840) \\
& \frac{\sqrt{\{(40 \times 262050)-(9840769)\}\{(40 \times 209696)-(80}}{r x y}= \\
& \frac{9145600-8909080}{\sqrt{\{10482000-9840769\}\{8387840-8065600}} \\
& r x y=\frac{236520}{\sqrt{\{641231\}\{322240\}}} \\
& r x y=\frac{236520}{\sqrt{206630277440}} \\
& r x y=\frac{236520}{454566,032} \\
& r \mathbf{x y}=\mathbf{0 , 5 2 0}
\end{aligned}
$$$$
\sqrt{\{(40 \times 262050)-(9840769)\}\{(40 \times 209696)-(8065606)} e p a d a \text { siswa kelas X IIS SMA Negeri } 1
$$

Selanjutnya, peneliti melihat $r$ tabel pada taraf signifikan dengan jumlah responden 40 adalah 0,403. Dan hasil perhitungan diperoleh 0,520 , yang berarti $r$ hitung $(0,520)>(0,403)$. Maka koefisien korelasi yang terjadi pada perhitungan di atas adalah signifikan. Dengan demikian, telah didapatkan suatu hubungan yang positif antara hasil tes penguasaan kosakata dengan hasil tes kemampuan menulis puisi dengan tema "lingkungan alam" pada siswa kelas $X$ IIS SMAN 1 Cigudeg Bogor.

Interpretasi data yang telah disajikan di atas mengacu pada permasalahan yang telah dirumuskan pada bagian pendahuluan. Masalah tersebut mempertanyakan apakah terdapat hubugan yang positif antara seseorang yang memiliki kemampuan dalam menguasai kosakata dengan salah satu keterampilan berbahasa yaitu keterampilan menulis puisi.

Dan hasil tes yang diberikan kepada siswa kelas X IIS SMA Negeri 1 Cigudeg Bogor bahwa telah tergambarkan tentang kelompok kriteria siswa kemampuan menulis puisi. Pertama, kelompok kriteria rendah sebesar $27,5 \%$. Kedua, kelompok kriteria sangat tinggi sebesar $15 \%$. Jika dilihat dari rata-ratanya bahwa pengelompokkan perolehan nilai di atas bahwa termasuk kriteria sedang. Dengan demikian, dapat disimpulkan bahwa kemampuan menulis puisi siswa kelas $X$ IIS SMA Negeri 1 Cigudeg termasuk dalam kriteria sedang.

Selanjutnya, hasil tes yang diberikan Cigudeg Bogor, bahwa telah tergambarkan tentang kelompok kriteria siswa penguasaan kosakata. Pertama, yang termasuk kelompok kriteria rendah sebesar $37,5 \%$. Kedua, kelompok kriteria sedang sebesar $42,5 \%$. Ketiga, kelompok kriteria tinggi sebesar $15 \%$. Dan kelompok kriteria sangat tinggi sebesar 5\%. Jika dilihat dari rata-ratanya bahwa pengelompokkan Perolehan nilai di atas bahwa termasuk kriteria sedang. Dengan demikian, dapat disimpulkan bahwa penguasaan kosakata siswa kelas $X$ IIS SMA Negeri 1 Cigudeg termasuk dalam kelompok kriteria sedang.

Untuk menunjukkan ada tidaknya hubungan antara penguasaan kosakata dengan kemampuan menulis puisi pada siswa kelas X IIS SMA Negeri 1 Cigudeg Bogor, maka dilakukan uji korelasi product moment. Berdasarkan hasil pengujian $\mathbf{r} \boldsymbol{x} \boldsymbol{y}$ hitung sebesar $\mathbf{0 , 5 2 0}$ dan $\mathbf{r}$ $\boldsymbol{x y}$ tabel pada korelasi product moment yaitu $\mathbf{0 , 4 0 3}$. Perbandingan nilai tersebut berarti $r$ hitung lebih besar daripada $r$ tabel $(0,520>0,403)$. Jadi, hasil pengujian dengan koefisien korelasi yang diperoleh dari hasil perhitungan bahwa rxy 0,520 yaitu POSITIF.

Dengan demikian $\mathrm{HO}$ di tolak, sedangkan $\mathrm{H} 1$ diterima. Artinya, terdapat hubungan yang signifikan antara penguasaan kosakata dengan kemampuan menulis puisi pada siswa kelas $X$ IIS SMA Negeri 1 Cigudeg. Pernyataan di atas telah terbukti dengan suatu hasil dari nilai $r$ hitung lebih besar daripada $r$ tabel. 
Selanjutnya, untuk menyatakan dan menentukan suatu tingkat korelasi koefisien antara variabel $X$ dengan variabel $Y$ atau antara penguasaan kosakata dengan kemampuan menulis puisi yang dijadikan sebagai kekuatan dari hasil penelitian ini, maka peneliti telah memilih untuk menggunakan suatu ukuran kriteria besarnya koefisien korelasi yang dikutip dari buku acuan Sugiyono. Adapun kriteria besarnya koefisein korelasi sebagai berikut.

Tabel 6. Hasil Interpretasi Koefisien

Korelasi

\begin{tabular}{|c|c|}
\hline Interva Koefisien & Interpretasi \\
\hline $0,000-0,199$ & Sangat rendah \\
\hline $0,200-0,399$ & Rendah \\
\hline $\mathbf{0 , 4 0 0}-\mathbf{0 , 5 9 9}$ & Sedang \\
\hline $0,600-0,799$ & Kuat \\
\hline & \\
$0,800-1,000$ & Sangat kuat \\
\hline
\end{tabular}

Berdasarkan perhitungan data hasil tes penguasaan kosakata dengan kemampuan menulis puisi yang menggunakan rumus Product moment bahwa nilai yang diperoleh yaitu 0,525. Dan Perolehan nilai tersebut berada pada posisi di antara 0,400 sampai dengan 0,599 . Maka, nilai yang diperoleh termasuk kategori interpretasi Sedang. Dan kategori ini merupakan suatu hal yang dinyatakan positif. Jadi, peneliti dapat mengambil sebuah simpulan bahwa tes penguasaan kosakata terdapat hubungan yang positif dengan tes kemampuan menulis puisi pada siswa kelas $X$ IIS SMA Negeri 1 Cigudeg Kecamatan Cigudeg Kabupaten Bogor.

\section{PENUTUP}

Berdasarkan hasil tes pengujian penelitian pada siswa kelas $X$ IIS SMA Negeri 1 Cigudeg Bogor, maka dapat ditarik suatu simpulan yang sesuai yaitu 1)Peserta didik kelas $X$ IIS SMA Negeri Cigudeg cukup menguasai kosakata. Perolehan tersebut dibuktikan dengan rumus perhitungan presentase yaitu $42,5 \%$ yang berarti penguasaan kosakata siswa kelas X IIS SMA Negeri Cigudeg termasuk dalam kelompok kriteria sedang. 2)Peserta didik kelas X IIS SMA Negeri 1 Cigudeg cukup mampu menulis puisi. Perolehan tersebut dibuktikan dengan rumus perhitungan presentase yaitu $42,5 \%$ yang berarti kemampuan menulis puisi siswa kelas $X$ IIS SMA Negeri 1 Cigudeg termasuk dalam kriteria sedang. 3)Terdapat hubungan yang positif antara hasil tes penguasaan kosakata dengan hasil tes kemampuan menulis puisi. Adanya hubungan tersebut ditunjukkan dengan besarnya koefisien korelasi rxy 0,525 melebihi batas yang telah ditentukan dengan $r$ tabel pada tingkat kesalahan 5\% yaitu 0,403. Artinya, nilai $r$ hitung lebih besar daripada nilai $r$ tabel, yakni $0,525>0,403$.

Dari hasil penelitian tes di atas, maka implikasinya adalah 1)Bagi peserta didik hendaknya meningkatkan penguasaan kosakata dengan sering membaca buku, novel, puisi dan lain-lain yang bersifat menambah penguasaan kosakata. Karena, dengan seringnya membaca buku atau yang lainnya dapat meningkatkan kemampuan menulis pada umumnya dan pada khususnya yaitu menulis puisi. 2)Bagi tenaga pendidik, hendaknya menjelaskan tentang tahapan dan teknik-teknik pembelajaran kosakata atau pengalaman siswa dalam mengenal dan memperoleh makna kata serta menganjurkan kepada siswa untuk memiliki buku Kamus Besar Bahasa Indonesia (KBBI) dan Pedoman Umum Ejaan Bahasa Indonesia (PUEBI) sebagai pedoman dalam penulisan. 3)Bagi sekolah, hendaknya mengadakan lomba menulis dan membaca puisi dengan memerhatikan unsur-unsurnya. Hal ini dapat memotivasi peserta didik dalam menulis puisi dengan baik.

\section{REFERENSI}

Dolet, Unaradjan, Dominikus. (2013). Metode Penelitian Kuantitatif. Jakarta: Universitas Atma Jaya.

K,Tri Rama.(2008). Kamus Lengkap Bahasa Indonesia. Surabaya: Karya Agung 
Riyanto, Yatim. (2010). Metodologi Penelitian Pendidikan. Surabaya:SIC

Santoso, Joko. (2013). Pantun Puisi Lama Melayu dan Pribahasa Indonesia. Yogyakarta: Araska

Silalahi, Uiber. (2015). Metode Penelitian Sosial Kuantitatif. Bandung: PT. Refika Aditama,

Tarigan, Henry Guntur. (2008). Menulis sebagai suatu keterampilan berbahasa. Bandung: Penerbit Angkasa

Gustiana. (2013). "The Effect of Journal Writing Technique and Students' Achievement Motivation Toward Writing Achiement of the Fourth Semester Students of English Education Departmen of Undiksha". (Online)

http://id.portalgaruda.org/?ref=brows e\&mod=viewjournal\&journal=7035\&a ction=search\&tsearch $=$ The + Effect +0 f++Journal+Writing+Technique+and +Students\&button=search+title+insid e+journal. Diakses pada 28 Mei 2018 pukul 23.00 WIB

Hariyanto. (2013). "Pengertian dan Tujuan Pembelajaran". (Online).

https://belajarpsikologi.com/pengerti an-dan-tujuan-

pembelajaran/\#Tujuan Pembelajara

n. Diunduh 5 Januari 2019 pukul 23.00 WIB

Kristina, Diah, Ayu., Shaifuddin., Sriyanto, M. Ismai. (2013). "Hubungan antara Penguasaan Kosakata dengan Kemampuan Menulis Puisi". (Online).

http://id.portalgaruda.org/?ref=brows e\&mod=viewarticle\&article $=107753$. Diakses: 01 Januari 2019.

Marsini. (2018). "Upaya Meningkatkan Kemampuan Menulis Cerita dengan Metode Sugesti Imajinasi melalui Media Pergelaran Wayang pada Siswa kelas IX A SMP Negeri 6 Semarang".

(Online). http://download.garuda.ristekdikti.go. id/article.php?article $=7150 \&$ val $=540$ \&title=UPAYA\%20MENINGKATKAN \%20KEMAMPUAN\%20MENULIS\%2
OCERITA\%20DENGAN\%20METOD E\%20SUGESTI\%20IMAJINASI\%20 MELALUI\%20MEDIA\%20PERGELA RAN\%20WAYANG\%20PADA\%20SI SWA\%20KELAS\%20IXA\%20SMP\% 20NEGERI\%206\%20SEMARANG.

Diakses: 18 Januari 2019

Susanti, Indri.,Triyono., Joharman. (2018). "Hubungan antara Penguasaan Unsur Intrinsik Puisi dan Minat Menulis Puisi dengan Kemampuan Menulis Puisi Kelas V Sekolah Dasar". (Online). http://download.garuda.ristekdikti.go. id/article. php?article $=273818 \& \mathrm{val}=40$ 73\&title=HUBUNGAN\%20ANTARA $\% 20 P E N G U A S A A N \% 20 U N S U R \% 2$ OINTRINSIK\%20PUISI\%20DAN\%20 \%20MINAT\%20MENULIS\%20PUISI \%20DENGAN\%20KEMAMPUAN\%2 OMENULIS\%20PUISI\%20\%20KELA S\%20V\%20SEKOLAH\%20DASAR. Diakses: 18 Januari 2019 